\title{
POTENSI DAN PERMASALAHAN SOSIAL EKONOMI MASYARAKAT PERIKANAN KABUPATEN LOMBOK TIMUR DALAM MENDUKUNG INDUSTRIALISASI
}

\author{
"Nurlaili, Cornelia M Witomo dan Achmad Zamroni \\ Balai Besar Penelitian Sosial Ekonomi Kelautan dan Perikanan \\ Gedung Balitbang KP I Lt. 4 \\ Jalan Pasir Putih Nomor 1 Ancol Timur, Jakarta Utara \\ Telp: (021) 64711583 Fax: 64700924 \\ *e-mail: lelykesa_antrop@yahoo.com \\ Diterima 10 Februari 2014- Disetujui 2 Nopember 2014
}

\begin{abstract}
ABSTRAK
Pembangunan berkelanjutan berbasis kawasan menjadi salah satu pendekatan pembangunan perikanan dalam mendukung industrialisasi. Untuk itu dibutuhkan data secara menyeluruh dan terperinci mengenai potensi sumberdaya perikanan dan manusianya agar kebijakan yang ada sesuai dengan tujuan industriaisasi. Makalah ini bertujuan untuk menggambarkan potensi perikanan dan permasalahan sosial ekonomi di Kabupaten Lombok Timur. Penelitian dilakukan pada tahun 2013 di Kabupaten Lombok Timur, Provinsi Nusa Tenggara Barat. Metode penelitian yang digunakan adalah metode kualitatif dengan teknik pengumpulan data wawancara mendalam (depth interview). Analisis data yang digunakan adalah analisis deskriptif kualitatif. Hasil identifikasi menunjukkan bahwa potensi sumberdaya perikanan di Kabupaten Lombok Timur sangat besar dan butuh sumberdaya manusia yang terampil dalam mengelola sumberdaya yang ada sehingga sektor perikanan dapat memberikan kesejahteraan sebesar-besarnya kepada masyarakat.
\end{abstract}

Kata kunci: potensi perikanan, permasalahan sosial ekonomi, industrialisasi, Lombok Timur

Abstract : Socio-Economic Potencies and Problems of Community in The East Lombok Regency To Support Fishing Industry by: Nurlaili, Cornelia M Witomo dan Achmad Zamroni

Sustainable development based on region become an approach to fisheries development to support industrialization. Detailed data on the fisheries resources and human potential that the existing policies in accordance with the purpose of industrialization. This paper aims to describe the potential of fisheries and socio-economic problems in East Lombok. The study was conducted in 2013 in East Lombok, West Nusa Tenggara Province. Method used is a qualitative method with data collection techniques in-depth interviews (depth interview). Analysis of the data used is descriptive qualitative analysis. The results showed that the identification of fish resources potencies in East Lombok are very large andskilled human resources are needed to manage the resources so that the fisheries sector can provide maximum welfare to society.

Keywords : fish potencies, socio-economic issues, industrialization, East Lombok

\section{PENDAHULUAN}

Industrialisasi lahir untuk mengatasi berbagai permasalahan sosial ekonomi seperti kemiskinan, pengangguran, dan rendahnya tingkat produksi yang ada di masyarakat. Smelser (1968) berpendapat bahwa industrialisasi mempunyai kaitan dengan pembangunan. Menurut Victor (2008), industrialisasi sebagai suatu usaha yang di dalamnya ada struktur dan proses melibatkan banyak pihak yang berkepentingan (stakeholder) dengan tujuan untuk meningkatkan kesejahteraan (terutama ekonomi) bagi pihak-pihak tersebut (Hikmah, 2012 : 2). Industrialisasi perikanan menurut Satria (2011) dapat dilihat melalui dua perspektif. Pertama, industrialisasi perikanan dalam arti sempit, yakni membangun pabrik-pabrik pengolahan ikan, yang tujuannya meningkatkan produksi ikan olahan, baik untuk pasar domestik maupun ekspor. Salah satu faktor yang terpenting adalah terjadinya pertumbuhan produksi, siapapun pelakunya dan dari manapun sumber bahan bakunya. Industrialisasi perikanan dalam arti luas adalah transformasi pelaku di hulu sampai hilir sehingga nelayan dan pembudidaya ikan juga menjadi penting dalam proses ini (Hikmah, 2012: 3-4). Lebih lanjut, Satria (2011) mengatakan bahwa industrialisasi tidak hanya sebatas membangun pabrik, tetapi lebih pada terciptanya sistem yang menjamin meningkatnya mutu produk perikanan nelayan dan pembudidaya ikan yang bernilai tambah, berkelanjutan dan mensejahterakan. Industri tidak hanya teknologi tetapi orientasi budaya baru, dimana industri mengait pada sumberdaya lokal sehingga pelaku lokal di hulu terlibat dalam menjamin keberlanjutan produksi (Hikmah, 2012: 4).

Ketersediaan sumberdaya perikanan yang melimpah namun realita kondisi masyarakatnya masih dalam keterpurukan dan kemiskinan menjadi 
latar belakang diperlukannya proses industrialisasi. Industrialisasi kelautan dan perikanan adalah integrasi sistem produksi hulu dan hilir untuk meningkatkan skala dan kualitas produksi, produktivitas, daya saing, dan nilai tambah sumberdaya kelautan dan perikanan secara berkelanjutan. Tujuan industrialisasi kelautan dan perikanan adalah terwujudnya percepatan pendapatan pembudidaya, nelayan, pengolah, pemasar, dan petambak garam. Sasaran yang akan dicapai melalui industrialisasi kelautan dan perikanan adalah meningkatnya skala dan kualitas produksi, produktivitas, daya saing, dan nilai tambah sumberdaya kelautan dan perikanan. Pendekatan industrialisasi kelautan dan perikanan dilakukan melalui penataan sistem dan manajemen yang mencakup yaitu pengembangan komoditas dan produk unggulan berorientasi pasar; Penataan dan pengembangan kawasan dan sentra produksi secara berkelanjutan; Pengembangan konektivitas dan infrastruktur; Pengembangan usaha dan investasi; Pengembangan iptek dan sumber daya manusia; Pengendalian mutu dan keamanan produk; Penguatan pengawasan pemanfaatan sumberdaya kelautan dan perikanan. Dengan dilaksanakannya industrialisasi kelautan dan perikanan yang dimulai secara bertahap sejak tahun 2012, maka ditargetkan diperoleh nilai tambah di sisi hulu dan hilir (KKP, 2012)

Untuk mengimplementasi prinsip-prinsip industrialisasi tersebut maka dibutuhkan modal baik sumberdaya alam maupun manusianya. Untuk itu dibutuhkan data secara menyeluruh dan terperinci mengenai potensi sumberdaya perikanan dan manusianya agar kebijakan yang ada dapat sesuai sehingga tujuan industriaisasi dapat tercapai. Identifikasi potensi dan permasalahan merupakan suatu upaya untuk memudahkan kita dalam menentukan suatu program pengembangan masyarakat yang dibutuhkan di dalam masyarakat. Dengan mengidentifikasi potensi dan permasalahan maka akan terlihat sumberdaya yang dimiliki serta ketimpangan-ketimpangannya yang terjadi (Rudito, 2008). Identifikasi potensi dan permasalahan sosial ekonomi masyarakat pesisir di Kabupaten Lombok Timur merupakan tahap awal dalam proses industrialisasi perikanan. Tulisan ini bertujuan menggambarkan potensi perikanan dan permasalahan sosial ekonomi di Kabupaten Lombok Timur dalam rangka menghadapi industrialisasi.

\section{METODE PENELITIAN}

Penelitian menggunakan pendekatan kualitatif dengan teknik pengumpulan data menggunakan teknik wawancara mendalam (depth interview). Kegiatan penelitian dilakukan pada tahun 2013 di Kabupaten Lombok Timur, Propinsi Nusa Tenggara Barat di beberapa lokasi penelitian yang dianggap mewakili karakteristik potensi sumberdaya yang ada di Kabupaten Lombok Timur yaitu sentra-sentra perikanan antara lain sentra perikanan pesisir di Kecamatan Keruak dan Jerowaru, sentra pengolahan di Rumbuk dan sentra perikanan air tawar di Masbagik. Analisis data menggunakan analisis deskriptif kualitatif dimana data-data yang ada digambarkan secara rinci dan dikaitkan dengan proses industrialisasi.

\section{HASIL PEMBAHASAN}

\section{Potensi Sumberdaya Kelautan dan Perikanan Kabupaten Lombok Timur}

Luas wilayah Kabupaten Lombok Timur sebesar 2.679,88 $\mathrm{km}^{2}$ dengan luas wilayah daratan $1.605,55 \mathrm{~km}^{2}$ dan luas wilayah laut $1.074,33 \mathrm{~km}^{2}$, sedangkan panjang pantai Lombok Timur adalah 220 km. Potensi Sumberdaya Kelautan dan Perikanan di Kabupaten Lombok Timur terdapat perikanan tangkap, budidaya, pegaraman, pengolahan hasil perikanan dan ekowisata.

Tabel 1. Jumlah Kapal Penangkapan Ikan di Kabupaten Lombok Timur Berdasarkan Landing Base Tahun 2011.

\begin{tabular}{lrrrr}
\hline Kecamatan & $\begin{array}{c}\text { Jukung dan } \\
\text { Perahu Sampan }\end{array}$ & $\begin{array}{c}\text { Perahu Motor } \\
\text { Tempel }\end{array}$ & Kapal Motor & Jumlah \\
\hline Keruak & - & 965 & 179 & 1144 \\
\hline Labuhan Haji & 50 & 237 & 2 & 289 \\
\hline Labuhan Lombok & 64 & 121 & 110 & 12 \\
\hline Jerowaru & 103 & 1540 & 39 & 4655 \\
\hline Sugian/Sambelia & 205 & 203 & 345 & 3891 \\
\hline Sakra Timur & 491 & 3055 & 345 & 3920 \\
\hline Jumlah & 437 & 3138 & 345 & 3911 \\
\hline 2010 & 437 & 3129 & 345 & 3929 \\
\hline 2009 & 461 & 3123 & 347 & 3931 \\
\hline 2008 & 501 & 3083 & 345 & 3891 \\
\hline 2007 & 491 & 3055 & & \\
\hline
\end{tabular}

Sumber : Dinas Kelautan dan Perikanan Kabupaten Lombok Timur (2012) dalam Zamroni;dkk (2013) 
Tabel 2. Jumlah Alat Tangkap di Kabupaten Lombok Timur Tahun 2011.

\begin{tabular}{|c|c|c|c|c|c|c|c|}
\hline Jenis Alat Tangkap & $\begin{array}{c}\text { Tanjung } \\
\text { Luar }\end{array}$ & $\begin{array}{c}\text { Labuhan } \\
\text { Haji }\end{array}$ & $\begin{array}{l}\text { Labuhan } \\
\text { Lombok }\end{array}$ & $\begin{array}{c}\text { Batu } \\
\text { Nampar }\end{array}$ & $\begin{array}{c}\text { Sugian/ } \\
\text { Sambelia }\end{array}$ & $\begin{array}{l}\text { Sakra } \\
\text { Timur }\end{array}$ & Jumlah \\
\hline Payang & 366 & - & 13 & 19 & - & - & 398 \\
\hline Purse Seine & 37 & - & 15 & - & - & - & 52 \\
\hline Jaring Insang $\mathrm{H}$ & 52 & 56 & 68 & - & 90 & 24 & 290 \\
\hline Jaring Insang TTP & 226 & 75 & 88 & 152 & 27 & 54 & 622 \\
\hline Jaring Lingkar Apung & 12 & - & - & - & 8 & - & 20 \\
\hline Jaring Klitik & 265 & 81 & 121 & 382 & 44 & 25 & 918 \\
\hline Bagan Tancap & 33 & - & - & 40 & - & - & 73 \\
\hline Bagan Sampan & - & - & 25 & - & 7 & - & 32 \\
\hline Pancing Rawai & 588 & 90 & 178 & 149 & 30 & 20 & 1055 \\
\hline Pancing Biasa & 409 & 215 & 92 & 205 & 334 & 175 & 1430 \\
\hline Pancing Tonda & 396 & 106 & 197 & 115 & 126 & 43 & 983 \\
\hline Pancing Ulur & 245 & 103 & 172 & 85 & 52 & 31 & 688 \\
\hline Pukat Pantai & 6 & - & 6 & - & - & - & 12 \\
\hline Bubu & 79 & 12 & - & 22 & 17 & 15 & 145 \\
\hline Jumlah & 2714 & 738 & 975 & 1169 & 735 & 387 & 6718 \\
\hline
\end{tabular}

Sumber : Dinas Kelautan dan Perikanan Kabupaten Lombok Timur (2012) dalam Zamroni;dkk (2013)

Pantai pasir putih dan pemandangan bawah laut dengan ekosistem terumbu karang serta ombak yang ideal menjadi potensi bagi pengembangan wisata bahari. Perikanan tangkap laut memiliki potensi sumberdaya ikan lestari (MSY) pada tahun 2008 mencapai 18.242,0 ton/ tahun antara lain ikan pelagis $7.752,8$ ton/tahun dan ikan demersal $10.489,2$ ton/tahun. Kabupaten Lombok Timur juga memiliki potensi perikanan budidaya laut antara lain produksi mutiara 0,22 ton; Ikan Kerapu 5,40 ton; Udang Lobster 82,90 ton; dan Rumput Laut 60.471,00 ton. Perikanan budidaya air tawar juga berpeluang besar untuk dikembangkan dengan kapasitas produksi yaitu kolam 851,00 ton; mina padi 3,60 ton dan karamba 1,40 ton. Jenis ikan yang dibudidayakan adalah ikan mas, nila, gurame, lele, bawal, patin, dan tawes. Selain perikanan budidaya ai tawar masih terdapat potensi perikanan budidaya air payau yaitu 1.074,50 ton udang vanamme; 352,70 ton udang windu dan 7,9 ton bandeng.

Jenis dan Jumlah kapal penangkapan ikan di Kabupaten Lombok Timur masih didominasi oleh kapal tradisional. Teknologi armada penangkapannya masih berukuran kecil sehingga jarak tempuh lokasi penangkapannya tidak terlalu jauh dari pantai. Jenis dan jumlah armada penangkapan ikan di Kabupaten Lombok Timur berdasarkan landing base dapat dilihat pada Tabel 1.

Tidak hanya armada kapal penangkapan ikan, jenis alat tangkap yang ada di masyarakat masih tergolong sederhana. Umumnya, nelayan menggunakan jenis pancing (20\%). Jenis dan jumlah alat tangkap yang digunakan oleh nelayan di Kabupaten Lombok Timur dapat dilihat pada Tabel 2.

Selain jenis alat tangkap yang sudah diuraikan pada tabel di atas, masih dapat ditemui adanya penggunaan alat tangkap yang destruktif di masyarakat seperti bom, obat bius, dan trawl. Hal ini dapat mengancam keberlanjutan sumberdaya yang tersedia.

Kabupaten Lombok Timur tidak hanya melimpah pada sektor perikanan tangkap saja, sektor budidaya juga menjadi potensi dan berpeluang besar untuk dikembangkan dalam rangka industrialisasi. Jenis budidaya yang ada di Kabupaten Lombok Timur yaitu budidaya tambak, kolam, dan sawah/keramba. Produksi perikanan budidaya seperti terlihat pada Tabel 3.

Sektor pengolahan hasil perikanan di Kabupaten Lombok Timur juga memiliki peluang untuk dikembangkan. Ketersediaan sumber bahan baku menjadi faktor pendorong bagi pengembangan pengolahan hasil perikanan. Diversifikasi berbagai produk hasil perikanan sudah banyak ditemui di masyarakat dan tersebar di beberapa desa. Namun, industri pengolahan hasil perikanan yang ada di Kabupaten Lombok Timur masih berada pada skala kecil industri rumah tangga dengan pemasaran masih untuk memenuhi kebutuhan lokal kabupaten dan sekitarnya. Produk-produk pengolahan hasil perikanan yaitu ikan bakar, pemindangan, minyak ikan, kerupuk, terasi, permen, dodol, rajungan kupas, pengasinan, tortila, tepung ikan, abon, bakso ikan dan teripang kering. 
Tabel 3. Jumlah Produksi Perikanan Budidaya dan Penangkapan di Kabupaten Lombok Timur Tahun 2012.

\begin{tabular}{|c|c|c|c|c|}
\hline \multirow{2}{*}{ Kecamatan } & \multicolumn{4}{|c|}{ Budidaya } \\
\hline & Tambak & Kolam & Sawah/Keramba & Jumlah \\
\hline Keruak & - & 59,70 & - & 59,70 \\
\hline Jerowaru & 20,91 & 570,60 & - & 591,51 \\
\hline Sakra & - & 5,50 & - & 5,50 \\
\hline Sakra Barat & - & 10,90 & - & 10,90 \\
\hline Sakra Timur & 464,10 & 4,80 & - & 468,90 \\
\hline Terara & & 19,50 & - & 19,50 \\
\hline Montong Gading & & 265,50 & 5,00 & 270,50 \\
\hline Sikur & & 27,50 & - & 27,50 \\
\hline Masbagik & & 246,30 & 0,20 & 246,50 \\
\hline Pringgasela & & 75,30 & 40,10 & 115,40 \\
\hline Sukamulia & & 24,90 & - & 24,90 \\
\hline Suralaga & & 39,35 & - & 39,35 \\
\hline Selong & & 60,50 & - & 60,50 \\
\hline Labuhan Haji & & 6,50 & - & 6,50 \\
\hline Pringgabaya & & 2,80 & - & 2,80 \\
\hline Suela & & 0,70 & - & 0,70 \\
\hline Aikmel & & 257,30 & 4,20 & 261,50 \\
\hline Wanasaba & & 23,70 & - & 23,70 \\
\hline Sembalun & & 0,70 & - & 0,70 \\
\hline Sambelia & $2.096,19$ & 0,75 & - & $2.096,94$ \\
\hline Jumlah & $2.581,20$ & $1.702,80$ & 49,50 & $4.333,50$ \\
\hline
\end{tabular}

Sumber : Dinas Kelautan dan Perikanan Kabupaten Lombok Timur (2012) dalam Zamroni;dkk (2013)

Tabel 4. Jenis Pengolahan, Bahan Baku dan Lokasi Pengolahan Hasil Perikanan di Kabupaten Lombok Timur.

\begin{tabular}{|c|c|c|c|c|}
\hline \multirow[t]{2}{*}{ No } & \multirow[t]{2}{*}{ Jenis Pengolahan } & \multirow[t]{2}{*}{ Jenis Bahan Baku } & \multicolumn{2}{|c|}{ Lokasi } \\
\hline & & & Desa/Kelurahan & Kecamatan \\
\hline 1 & Ikan Bakar & Sulir, Kembung, Cakalang, Gurita & Desa Danerase & Keruak \\
\hline 2 & Pemindangan & & $\begin{array}{l}\text { Desa Menanga Baris Desa } \\
\text { Gunung Malang Desa Rumbuk }\end{array}$ & $\begin{array}{l}\text { Pringabaya, Pringabaya } \\
\text { Sakra } \\
\text { Sambelia }\end{array}$ \\
\hline 3 & Minyak Ikan & Hati Hiu & Desa Tanjung Luar & Keruak \\
\hline 4 & Kerupuk & $\begin{array}{l}\text { Kulit Hiu, } \\
\text { Kakap Merah }\end{array}$ & $\begin{array}{l}\text { Desa Rumbuk } \\
\text { Desa Labuan Haji }\end{array}$ & $\begin{array}{l}\text { Sakra } \\
\text { Keruak }\end{array}$ \\
\hline 5 & Kerajinan Kulit & Kulit Pari & Desa Rumbuk & Sakra \\
\hline 6 & Kerupuk & Rumput Laut & $\begin{array}{l}\text { Desa Lendang Nangka Desa } \\
\text { Kedome }\end{array}$ & $\begin{array}{l}\text { Masbagik } \\
\text { Sakra }\end{array}$ \\
\hline 7 & Terasi & Udang Rebon & $\begin{array}{l}\text { Desa Jor } \\
\text { Pemongkong }\end{array}$ & $\begin{array}{l}\text { Jerowaru } \\
\text { Jerowaru }\end{array}$ \\
\hline 8 & Permen dan Dodol & Rumput Laut & Desa Ketapang Raya & Keruak \\
\hline 9 & Rajungan Kupas & Rajungan & $\begin{array}{l}\text { Desa Pemongkong } \\
\text { Desa Ujung Betok }\end{array}$ & $\begin{array}{l}\text { Jerowaru } \\
\text { Jerowaru }\end{array}$ \\
\hline 10 & Pengasinan & Layar, Lembayan & $\begin{array}{l}\text { Desa Labuan Lombok } \\
\text { Desa Tanjung Luar Desa } \\
\text { Ketapang Raya } \\
\text { Desa Rumbuk }\end{array}$ & $\begin{array}{l}\text { Keruak } \\
\text { Keruak } \\
\text { Keruak } \\
\text { Sakra } \\
\end{array}$ \\
\hline 11 & Tortila & & $\begin{array}{l}\text { Desa Rumbuk } \\
\text { Desa Seruni }\end{array}$ & $\begin{array}{l}\text { Sakra } \\
\text { Selong }\end{array}$ \\
\hline 12 & Abon & Tenggiri & Desa Wanasaba & Wanasaba \\
\hline 13 & Teripang Kering & Teripang & Desa Danerase & Keruak \\
\hline 14 & Bakso Ikan & & Kel Kembang Sari & Selong \\
\hline 15 & Tepung Ikan & Kepala Ikan & Desa Tanjung Luar & Keruak \\
\hline
\end{tabular}

Sumber : Dinas Kelautan dan Perikanan Kabupaten Lombok Timur (2012) dalam Zamroni;dkk (2013) 
Hampir seluruh desa di Kabupaten Lombok Timur telah menghasilkan produk olahan perikanan yaitu Keruak, Pringgabaya, Sakra, Sambalia, Masbagik, Jerowaru, Selong, dan Wanasaba dengan sentra pengolahan hasil perikanan di Desa Rumbug. Sebaran desa yang menjadi penghasil pengolahan perikanan dapat dilihat pada Tabel 4.

Produk kelautan dan perikanan di Kabupaten Lombok Timur selain perikanan adalah garam. Data produksi garam pada tahun 2012 sebesar 10.200.54 ton. Jumlah produksi tersebut akan semakin besar jika lahan-lahan yang saat ini belum termanfaatkan dapat dioptimalkan sebagai tambak garam. Sisa produksi garam pada tahun 2012 di petambak garam sebesar $26 \%$ atau mencapai $2.742,05$ ton dan masih tersimpan di gudang-gudang penyimpanan. dapat mengoptimalkan pemanfaatan sumberdaya yang tersedia. Skala usaha di masyarakat masih skala kecil dan umumnya belum mengarah pada produktivitas usaha yang besar. Demikian halnya dengan sumberdaya manusia yang masih rendah dengan kecenderungan budaya subsistem, konsumtif dan individualis.

\section{Permasalahan Sosial Ekonomi Masyarakat Perikanan di Kabupaten Lombok Timur}

Potensi sumberdaya kelautan dan perikanan yang cukup besar namun pada kenyataannya masih memberikan kontribusi yang rendah terhadap pendapatan daerah Kabupaten Lombok Timur. Kontribusi sektor kelautan dan perikanan yang tergabung dalam sektor primer masih jauh dibandingkan dengan sektor tersier seperti perdagangan, hotel,

Tabel 5. Data Produksi Garam Kabupaten Lombok Timur Tahun 2012.

\begin{tabular}{llcc}
\hline \multirow{2}{*}{ Kecamatan } & \multicolumn{1}{c}{ Desa } & Data Produksi 2012 (ton) & $\begin{array}{c}\text { Sisa Produksi/ } \\
\text { Stok di Petani (Ton) }\end{array}$ \\
\hline Jerowaru & Jerowaru & 931,07 & 236,30 \\
\hline & Pemongkong & $4.908,30$ & 924,80 \\
\hline & Seriwe & 990,14 & 189,95 \\
\hline & Sekaroh & $1.603,55$ & 618,50 \\
\hline Keruak & Pandan Wangi & 335,05 & 59,50 \\
\hline & Batu Nampar Selatan & 318,45 & 300,00 \\
\hline Jumlah & Ketapang Raya & 956,20 & 375,00 \\
\hline
\end{tabular}

Sumber : Dinas Kelautan dan Perikanan Kabupaten Lombok Timur (2012) dalam Zamroni;dkk (2013)

Ekowisata sumberdaya kelautan di Kabupaten Lombok Timur memiliki potensi yang cukup besar. Kondisi terumbu karang yang masih alami menjadi daya tarik untuk pengembangan wisata laut. Demikian juga dengan pasir putih dan pemandangan alamnya yang sangat indah dapat menjadi daya tarik wisatawan baik domestik maupun mancanegara. Ombak yang ideal juga sangat potensial untuk dimanfaatkan oleh para wisatawan untuk kegiatan berselancar. Beberapa pantai yang memiliki potensi untuk ecowisata antara lain pantai Surga dan Pantai Pink yang terletak di Kecamatan Jerowaru. Kedekatan posisi dengan Pulau Bali menjadi potensi bagi pengembangan wisata bahari terutama keberadaan pulau-pulau kecil (gili) dengan pantai dan pasir putih yang dapat dijadikan daya tarik bagi wisatawan. Sektor wisata bahari diharapkan dapat menjadi sumber pendapatan ekonomi di Kabupaten Lombok Timur.

Sumberdaya kelautan dan perikanan yang potensial di masyarakat masih belum dapat memberikan kesejahteraan secara optimal. Berbagai faktor penyebabnya antara lain faktor teknologi, sumberdaya manusia dan budaya yang dimiliki masyarakat. Dari aspek teknologi, masih rendahnya teknologi yang digunakan oleh masyarakat menyebabkan masyarakat belum restoran, sektor pengangkutan dan komunikasi, sektor keuangan, real estate, jasa perusahaan serta sektor jasa-jasa lainnya. Sejak tahun 2007-2011, sektor tersier mengalami peningkatan yang cukup besar dan signifikan jika dibandingkan dengan sektor primer. Gambaran kontribusi primer, sekunder dan tersier terhadap PDRB di Kabupaten Lombok Timur dapat dilihat pada Gambar 1 di bawah ini.

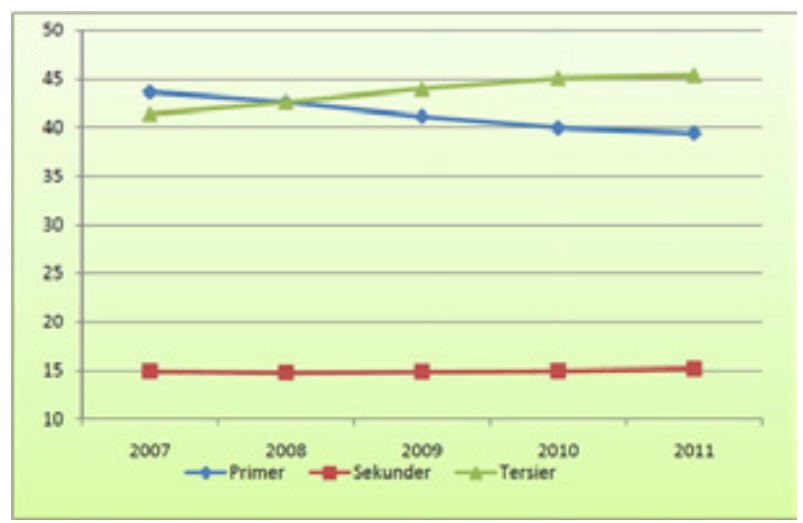

Sumber : Zamroni; dkk, 2013

Gambar 1. Kontribusi Sektor Ekonomi Terhadap PDRB Kabupaten Lombok Timur adalah Berlaku Tahun 2007-2011 (\%). 
Penduduk Kabupaten Lombok Timur pada tahun 2011 berjumlah sekitar 1.116.745 jiwa, mengalami peningkatan sekitar 1,01 persen dibandingkan tahun 2010. Jumlah angkatan kerja 65,01 \% dari total penduduk, 62,03 \% dari total penduduk merupakan pekerja, sedangkan 2,98 \% merupakan pengangguran. Sebagian besar mata pencaharian penduduk Lombok Timur di sektor pertanian, kemudian di bidang perdagangan, jasa, angkutan dan komunikasi. Sektor pertanian termasuk di dalamnya nelayan. Masyarakat pesisir memiliki mata pencaharian sebagai nelayan, pembudidaya, maupun pengolah hasil perikanan. Pekerjaan tersebut secara turun temurun dilakukan dari generasi ke generasi. Selain bekerja di sektor perikanan, dapat ditemukan sebagian besar anggota masyarakat di Kabupaten Lombok Timur yang bekerja di luar negeri. Umumnya mereka bekerja di Malaysia dan Arab Saudi (BPS Kabupaten Lombok Timur, 2012 dalam Zamroni;dkk (2013)). Mereka bekerja di luar negeri dengan harapan menginginkan kehidupan ekonomi yang lebih baik. Dilihat dari tingkat pendidikan umumnya masyarakat perikanan memiliki tingkat pendidikan yang rendah, umumnya SD atau tidak bersekolah.

Masyarakat perikanan di Kabupaten Lombok Timur merupakan suku asli Lombok yang dikenal dengan suku Sasak. Berdasarkan indikator kebutuhan keluarga, pada tahun 2011 Kabupaten Lombok Timur tergolong ke dalam kategori Keluarga Pra Sejahtera dan Keluarga Sejahtera I (BPS Kabupaten Lombok Timur, 2012 dalam Zamroni;dkk (2013)).

Kondisi kemiskinan makin terlihat pada masyarakat nelayan di pesisir, umumnya mereka hidup dalam kekurangan. Faktor penyebab kemiskinan antara lain rendahnya teknologi dalam usaha, ikatan hutang dan kecenderungan konsumerisme pada masyarakat. Berdasarkan hasil wawancara dengan tokoh masyarakat dan stakeholder terkait masyarakat nelayan umumnya tidak memiliki manajemen pengelolaan keuangan rumah tangga yang baik. Pada saat hasil tangkapan berlimpah, mereka cenderung menghabiskan pendapatan untuk dibelanjakan keperluan rumah tangga non produktif seperti barang elektronik. Kondisi tersebut menyebabkan mereka tidak memiliki tabungan untuk menghadapi kondisi paceklik. Ketiadaan tabungan ini menyebabkan pada saat musim paceklik mereka mengambil pinjaman kepada bos atau pemberi pinjaman seperti rentenir atau tengkulak. Budaya menyimpan uang di koperasi atau di lembaga keuangan formal lainnya masih rendah. Masyarakat umumnya lebih senang menyimpan uang di rumah seperti di bawah bantal dengan alasan lebih mudah mengambilnya jika sewaktu-waktu membutuhkan uang tersebut.

Etos kerja masyarakat pesisir di Kabupaten Lombok Timur umumnya rajin. Hal ini terlihat dari curahan waktu yang mereka keluarkan. Hampir tidak ada waktu luang untuk santai-santai. Mereka lebih senang mengisi waktu luang dengan kegiatan yang dapat menghasilkan uang atau yang disebut dengan poro poro. Hal ini dilakukan oleh laki-laki maupun perempuan. Dalam pembagian tugas mereka tidak membedakan gender antara laki-laki dan perempuan. Tidak sedikit kaum perempuan yang bekerja membantu perekonomian keluarga. Namun, dari sisi pengetahuan dan keterampilan mereka umumnya harus dilatih dan dilakukan pendampingan untuk menumbuhkan semangat usaha yang tinggi. Sebagai contoh pada teknik budidaya ikan kerapu, masyarakat umumnya hanya mengandalkan pengetahuan sederhana yang mereka miliki baik pada saat pemeliharaan, pemberian pakan dan penanganan penyakit masih sangat jauh dari teknik budidaya yang baik dan benar. Demikian juga dalam hal pemanfaakan peluang potensi sumberdaya dan pasar, mereka masih sangat terbatas sehingga butuh pelatihan dan pendampingan.

Kelembagaan pengelolaan sumberdaya kelautan dan perikanan di masyarakat Kabupaten Lombok Timur dikenal dengan istilah awig awig. Awig awig merupakan hukum adat yang dibuat dengan tujuan menyelesaikan konflik yang terjadi dalam pengelolaan dan pemanfaatan sumberdaya kelautan dan perikanan di wilayah Lombok Timur. tujuan dibentuknya kelembagaan awig awig adalah untuk menjaga keberlanjutan sumberdaya dan meminimalisir potensi konflik dalam pemanfaatannya. Awig awig merupakan satu bentuk kearifan lokal dimana menjadi salah satu dari kebudayaan masyarakat setempat. Kebudayaan merupakan pedoman masyarakat dalam bersikap dan berperilaku. Kebudayaan merupakan sebuah sistem pengetahuan, gagasan, dan ide yang dijadikan landasan pijak dan pedoman bagi suatu kelompok masyarakat dalam bersikap dan berperilaku, baik di dalam lingkungan alam maupun lingkungan sosial mereka (Goodenough 1971, Spradley 1972, dan Geertz 1973, Suparlan (1986) dalam Thohir (1999)).

Kendala lainnya dalam pengembangan sektor kelautan dan perikanan di Kabupaten Lombok Timur adalah minimnya infrastruktur pendukung seperti ketersediaan listrik, dan SPBU/SPDN terkait bahan bakar yang minim, serta kondisi jalan yang belum mendukung

Tabel 6. Banyaknya Keluarga Berdasarkan Tingkat Kesejahteraan di Kabupaten Lombok Timur, Tahun 2008 - 2011.

\begin{tabular}{lcccc}
\hline \multicolumn{1}{c}{ Jenis Keluarga Berdasarkan } & \multicolumn{4}{c}{ Tahun } \\
\cline { 2 - 5 } Tingkat Kesejahteraan & $\mathbf{2 0 0 8}$ & $\mathbf{2 0 0 9}$ & $\mathbf{2 0 1 0}$ & $\mathbf{2 0 1 1}$ \\
\hline Keluarga Pra Sejahtera & 143.794 & 144.667 & 135.174 & 102.861 \\
Keluarga Sejahtera I & 144.135 & 144.408 & 151.879 & 189.064 \\
\hline
\end{tabular}

Sumber : BPS Kabupaten Lombok Timur (2012) dalam Zamroni; dkk (2013) 
untuk pengembangan ekowisata bahari. Rendahnya teknologi armada dan alat penangkapan pada nelayan serta keterbatasan pakan dan bibit untuk budidaya saat ini masih menjadi kendala dalam pengembangan usaha perikanan di Kabupaten Lombok Timur. Dalam usaha pengolahan hasil perikanan, masalah kemasan dan pemasaran juga menjadi kendala yang hampir ditemui di seluruh pelaku usaha di Kabupaten Lombok Timur. Stabilitas harga pada komoditas garam juga membuat pengembangan usaha garam terhambat di Kabupaten Lombok Timur.

Arah kebijakan pembangunan sektor kelautan dan perikanan adalah menjadikan Indonesia sebagai penghasil produk kelautan dan perikanan terbesar, bernilai tambah dan berdaya saing dalam rangka mensejahterakan masyarakat kelautan dan perikanan. Untuk dapat mewujudkan arah kebijakan tersebut maka dibutuhkan industriaisasi dalam sektor kelautan dan perikanan. Industrialisasi sektor kelautan dan perikanan bertujuan meningkatkan produksi, produktivitas, dan nilai tambah produk kelautan dan perikanan yang berdaya saing tinggi; berorientasi pasar; Mempercepat pembangunan ekonomi berbasis kelautan dan perikanan melalui modernisasi sistem produksi dan manajemen dan Meningkatkan kesejahteraan masyarakat kelautan dan perikanan.

Proses industrialisasi dilaksanakan berdasarkan 6 (enam) prinsip yaitu meningkatkan nilai tambah dan daya saing dengan peningkatan nilai tambah dan daya saing produk untuk ekspor dan memenuhi kebutuhan dalam negeri; Modernisasi sistem produksi dengan efisiensi dan modernisasi sistem produksi hulu dan hilir; Penguatan pelaku industri kelautan dan perikanan yaitu dengan meningkatkan jumlah, kapasitas, dan kualitas industri kelautan dan perikanan dan pembinaan hubungan antar entitas bisnis dan industri pada semua tahapan value chain untuk memperkuat struktur industri kelautan dan perikanan; Berbasis komoditas, wilayah dan sistem manajemen dengan konsentrasi pada komoditas unggulan, potensi wilayah dan manajemen sentra-sentra produksi potensial sesuai dengan prospek pertumbuhannya di masa depan; Berkelanjutan yaitu prinsip keseimbangan antara pemanfaatan sumberdaya alam dan perlindungan lingkungan berjangka panjang; Transformasi sosial yaitu perubahan cara berfikir dan perilaku masyarakat modern. Strategi implementasi industrialisasi yaitu pengembangan komoditas dan produk kelautan dan perikanan berbasis pasar, pengembangan kawasan, pengembangan konektivitas, pengembangan iklim usaha dan investasi, pengembangan teknologi dan sumberdaya manusia, serta penataan sistem manajemen.

Pengembangan kapasitas sumberdaya manusia dan transformasi sosial memiliki sasaran pada peningkatan kompetensi generasi muda nelayan, pembudidaya ikan, dan pengolah ikan melalui pendidikan; Peningakatn ketrampilan dan kompetensi nelayan, pembudidaya ikan dan pengolah ikan melalui pelatihan; Peningkatan kesadaran dan ketrampilan pelaku utama dan pelaku usaha perikanan melalui penyuluhan; dan Terbentuknya masyarakat industri kelautan dan perikanan MADANI. Untuk mewujudkan sumberdaya manusia yang handal maka dibutuhkan penyelenggaraan pendidikan kelautan dan perikanan berkualitas berstandar internasional pada tingkat SLTA, Akademi dan Perguruan Tinggi; Pengembangan sistem pendidikan terapan melalui factory teaching; Pengembangan kelembagaan pendidikan inovatif; Mengembangkan jaringan usaha antar alumni dengan industri; Penyelenggaraan pelatihan dengan standar kompetensi yang dibutuhkan untuk peningkatan produksi perikanan; Penyelenggaraan penyuluhan di sentra-sentra produksi dan lokasi potensial lainnya untuk meningkatkan kinerja produksi para pelaku utama dan pelaku usaha; Meningkatkan kapasitas penyuluh dan kualitas materi penyuluhan sesuai dengan standar kebutuhan.

\section{KESIMPULAN DAN REKOMENDASI}

Potensi kelautan dan perikanan yang potensial dikembangkan di Kabupaten Lombok Timur yaitu : perikanan tangkap (sumberdaya ikan pelagis besar); perikanan budidaya (pengembangan budidaya kerapu dengan metode karamba jaring apung (KJA), pembesaran lobster, pengembangan budidaya ikan nila dan lele, budidaya rumput laut, Kawasan budidaya mutiara); pengolahan produk hasil perikanan (pembuatan tepung ikan, pengolahan rajungan, ikan kering, pengolahan tripang, pengasapan ikan, kerupuk, dodol, manisan dan tortila); produk kelautan pengembangan metode produksi garam dari tradisional ke metode yang lebih modern; dan wisata bahari

Permasalahan - permasalahan yang menghambat pengembangan potensi kelautan dan perikanan di Kabupaten Lombok Timur yaitu masih minimnya teknologi pemanfaatan sumberdaya sehingga skala usaha masyarakat masih bersifat tradisional, dukungan infrastruktur yang masih minim serta masih rendahnya kapasitas sumberdaya manusia menjadi kendala dalam pengembangan sumberdaya kelautan dan perikanan di Kabupaten Lombok Timur.

Berdasarkan potensi dan permasalahan di atas maka untuk mendukung proses industrialisasi di sektor kelautan dan perikanan di Kabupaten Lombok Timur harus memperhatikan berbagai faktor yang ada antara lain meningkatkan nilai tambah dan daya saing produkproduk unggulan seperti rumput laut dan lobster baik untuk ekspor maupun kebutuhan dalam negeri; Modernisasi sistem produksi di masyarakat dengan efisiensi dan modernisasi sistem produksi hulu dan hilir; Penguatan pelaku industri kelautan dan perikanan di Kabupaten Lombok Timur dengan meningkatkan jumlah, kapasitas, dan kualitas industri kelautan dan perikanan serta pembinaan hubungan antar entitas 
bisnis dan industri pada semua tahapan value chain di Kabupaten Lombok Timur untuk memperkuat struktur industri kelautan dan perikanan; Berbasis komoditas, wilayah dan sistem manajemen dengan konsentrasi pada komoditas unggulan, potensi wilayah dan manajemen sentra-sentra produksi potensial sesuai dengan prospek pertumbuhannya di masa depan dan berkelanjutan yaitu prinsip keseimbangan antara pemanfaatan sumberdaya alam dan perlindungan lingkungan berjangka panjang dengan merevitalisasi kelembagaan awig awig; Transformasi sosial yaitu perubahan cara berfikir dan perilaku masyarakat modern dengan membangun budaya usaha yang maju seperti pola pikir ke depan dan merubah gaya hidup konsumerisme menjadi produktif.

Untuk mewujudkan proses transformasi sosial maka dibutuhkan peningkatan pengetahuan dan keterampilan melalui proses pelatihan dan pendampingan baik di sektor perikanan tangkap, budidaya, pegaraman, dan pengolahan hasil perikanan. Peningkatan modernisasi teknologi sangat dibutuhkan dalam rangka meningkatkan produktivitas usaha di masyarakat. Dengan memaksimalkan potensi sumberdaya kelautan dan perikanan yang tersedia dan meminimalisir berbagai persoalan sosial ekonomi dan budaya maka proses industrialisasi perikanan di Kabupaten Lombok Timur akan lebih cepat terwujud.

\section{DAFTAR PUSTAKA}

Hikmah dan Riesty Triyanti. 2012. “Pengembangan Industrialisasi Perikanan Budidaya : Konsep dan Implementasi" dalam buku Industrialisasi Perikanan Budidaya : Peluang, Permasalahan dan Tantangan. Jakarta : Balai Besar Penelitian Sosial Ekonomi Kelautan dan Perikanan.
Mohd.Nain, Achmad Shukri dan Rosman bin Mohd Yusoff. 2003. Konsep, Teori, Dimensi dan Isu Pembangunan. Johor : Fakulti Pengurusan dan Pembangunan Sumber Manusia, UTM, Skudai. Dapat diunduh pada laman http:// books.google.co.id/books?id=UJJK37WCyRQ C\&pg=PA24\&lpg=PA24\&dq=konsep+industr ialisasi\&source=b|\&ots=yZE 8 Givbsa\&sig=QJ OMDrIsAZ5IzITCNOqqEIQByII\&hl=en\&sa=X\& ei=127oUrTcC4KJrQevyYHQCQ\&sqi=2\&redir e $s c=y \# v=o n$ e $p$ a g e $\& q=k$ on s e p $\% 20$ industrialisasi\&f $=$ false

Kementerian Kelautan dan Perikanan. 2012. Peraturan Menteri Kelautan dan Perikanan Repubik Indonesia No. PER. 15/ MEN/ 2012. Rencana Strategis Kementerian Kelautan dan Perikanan Tahun 2010-2014. Diunduh http://www.kkp. go.id/public/upload/RENSTRA\%202012.PDF.

Kementerian Kelautan dan Perikanan. 2012. Kebijakan Industrialisasi Kelautan dan Perikanan Kementerian Kelautan dan Perikanan. 7 MARET 2012. Dapat diunduh pada laman http://www. infohukum.kkp.go.id/2.pdf. diunduh tanggal 29 Januari 2014.

Thohir, Mudjahirin. 1999. Wacana Masyarakat dan Kebudayaan Jawa Pesisiran. Semarang : Bendera

Zamroni, Achmad; dkk. 2013. Laporan Teknis Kegiatan KIMBIs Lombok Timur. Jakarta : Balai Besar Penelitian Sosial Ekonomi Kelautan dan Perikanan. 